\title{
Impact of Psychological Contract Breach and Psychological Contract Fulfillment on Employees' Intention to Quit In Telecom Sector of Pakistan
}

\author{
Adina Paracha \\ Department of Business Administration, Foundation University, Rawalpindi, Pakistan
}

\begin{abstract}
Purpose The paper is proposed in order to examine the relationship between psychological contract breach and fulfillment on employees' intention to quit. It seeks to present two simultaneous hypotheses, based on theoretical relations effects of all the three variables (psychological contract breach, fulfillment and intention to quit).

Design - The data was collected from a sample of 300 employees in telecom sector of Rawalpindi/Islamabad, Pakistan. Correlation/Regression analysis was used to explore the relationships between psychological contract breach, fulfillment and employees' intention to quit.

Findings - A positive relationship was found between psychological contract breach and intention to quit behavior of employees and a negative relationship between psychological contract fulfillment and intention to leave.

Research limitations/implications -Future research can however focus on the conditions under which psychological contract both breach and fulfillment will have an impact on employee's intention to leave the organization.
\end{abstract}

Keywords: Psychological contract breach, Psychological contract fulfillment, Intention to quit.

\section{Introduction}

Employees are considered to be the valuable asset of an organization and the survival and prosperity of the organization can be interpreted by scrutinizing their treatment with the employees (Hadijimanolis, 2000). A lot of hard work has been done by the organizations to attract eligible employees and uphold them in the organization. At the same time, organizations face the issue of employees' leaving the organizations. The matter of employees' intention to quit is researched at a large scale because it affects the organizational progress and labor productivity (Aladwan, Bhanugopan, \& Fish, 2012). Employees may leave the organization due to unfavorable working environment, job dissatisfaction, lack of commitment and work related attitudes (Griffin and Moorhead, 2011).

One of the most prominent determinant which effect the employees is psychological contract in either of its dimension i.e fulfillment, breach and violation. Many researchers (see for review: Coyle-Shapiro, 2002; Robinson, 1996; Robinson, Kraatz \& Rousseau; Turnley \& Feldman, 1998; 2000) contented that psychological contract breach has an adverse impact on the employees' intentions to work for the organization.

Thus the study focuses on psychological contract both breach and fulfillment which are treated as independent variables, that impact on Employee's intention to quit being the dependent variable. Psychological contract breach captures employees' perceptions of the extent to which the employer has failed to fulfill one or more of its obligations (Conway and Briner, 2005) whereas, fulfillment is otherwise.

\section{Statement of Research questions}

a) What effect does psychological contract breach have on employee's intention to quit in organizations?

b) How Psychological contract fulfillment helps to lessen employee's intentions to quit the organization?

\section{Objectives}

The objectives of this study are:

a) To examine the relationship between psychological contract breach and fulfillment with employee's intention to quit in telecom sector of Pakistan.

b) It seeks to present two simultaneous hypotheses, based on theoretical relations effects of all the three variables (Psychological contract breach, Psychological contract fulfillment and employee's intention to quit).

c) Focus on psychological contract (breach and fulfillment) as a key predictor of employee's intention to quit in organizations. 


\section{Significance of the Study}

This study is an attempt to increase the current level of knowledge of the existing literature on Psychological contract (breach, fulfillment) specially, in Pakistan as well as for the rest of the world. Considering its theoretical contribution, first, this study contributes to the body of literature on the above mentioned variables and their effects, particularly, with respect to the factors that are generally perceived today as the most demanding for success, survival and sustainability for any organization and one of those factors is Employee's intention to quit.

\section{Literature Review}

Intention to Quit

Intention o quit can be defined in the words of Masroor \& Fakir,(2010), An employees' plan or intention to leave the present job and look forward to find another job in the near future.

According to griffin and Moorhead (2011), employees' intention to leave the organization can be determined by commitment to work, job satisfaction and work related stance. Intention to quit is extensively researched because of the importance it holds towards the success of an organization and labor productivity. Intention to quit not only specify unfavorable working environment, but the organization may also suffer from loss of experienced workers and good customer relationship. (Aladwan, Bhanugopan, Fish, 2012)

Employees' intention to leave the organization is related with the direct and indirect cost. The direct cost includes bring in a replacement, employment, management, recruitment and selection. In addition to this it is low morale, training for the new employees, loss of social capital and pressure on other employees triggers the indirect cost of an organization (Griffin and Moorhead, 2011).

There may be a number of types of employee turnover. It can be voluntary, involuntary, functional, dysfunctional, uncontrollable or controllable (Mathis and Jackson, 2010). Voluntary turnover depends on the choice of an employee if he/she wants to continue or leave the organization, while involuntary turnover might be the result of employee's poor performance. The termination of unproductive or troublesome employees is functional turnover whereas; when extremely productive and key employees leave the organization it is known to be the dysfunctional turnover. Uncontrollable factors are those which are beyond management's authority whilst controllable turnover can be partial. Absenteeism also a major determinant of intention to quit. (Cohen and Golan, 2007).

\section{Psychological Contract (PC)}

Psychological contract had been center of attention for many researcher for quite a long span. In 1989, Rousseau defined it as a mutual association between the employer and the employee based on terms and conditions. Thus Conway and Briner (2002) proposed that:

"Psychological contracting is an exchange process, in which breaches or fulfillments initially are events that happen at work or in relation to work" (Geurrero and Herrbach, 2008),

Moreover, Sylvie Guerrero and Olivier Herrbach (2008), proposed that breach or fulfillment are not two distinct events rather they are two edges i.e high or low which depicts that whether the organization has failed to met the obligations or have successfully done it.

\section{Psychological Contract Breach (PCB)}

Morrison and Robinson (1997) proposed that psychological contract breach is actually the failure of an organization lacking behind in fulfilling the obligations towards the employees of the organization (Matthijs Bal, W. Jansen, S. Chiaburu). Since psychological contract breach takes into account a set of unpredicted obligations and events that may become a hindrance between the employee and employer relationship fostering negative effects towards the workplace.

Lester (2002) suggested that the employees will have a lower level of commitment and lowered job performance who will witness their psychological contract being breached. Moreover, Conway \& Briner (2002), suggested that psychological well being is reduced when the contract is breached, and an employee is more eager to leave the organization (Tekleab \& Taylor, 2003; Turnley \& Feldman, 1999).

This paper aims to highlight the association between the preception of psychological contract breach and fulfillment an organization contains, and the impact towards retention. The empirical work reveals that psychological contract breach is quite frequently observed and this could elucidate the problems faced by organizations in retaining their workforce

\section{Psychological Contract Fulfillment (PCF)}

Coyle-Shapiro and Kessler, (2002) suggested that psychological contract fulfillment generate the feeling of being appreciated in the employee which in turn put forth to positive affective outcomes for the organization. 
The fulfillment of psychological contract signifies the commitment of an employer towards an employee. In accordance with the Equity theory (Adams, 1963), if the contract is fulfilled, the employees respond in a positive behavior in the employment relationship. Therefore, employees who are contended with the encouragement from the employer may have high trust towards the organization which in turn will minimize or lessen their intention to quit the job.

Conway \& Briner (2002) argued that employees with fulfilled contract have high level of commitment towards the organization, better task performance, and high level of attachment with their supervisor and lower level of turnover intentions.

Social exchange theory (Blau, 1964) highlights that those employees who believe that the employer has fulfilled their expectations and treated them well will be more likely to perform their task better.

Many researchers (Robinson, 1996; Turnley \& Feldman, 2000; De Vos, Buyens \& Schalk, 2003; Raja, Johns \& Ntalianis, 2004; Psycones, 2006), acknowledge that employees will have a positive attitude which includes task performance, less intention to leave, if the contract is being fulfilled.

\section{Theoretical Framework}

This study examines the impact of Psychological contract breach and fulfillment with employee's intention to quit in telecom sector of Pakistan. The conceptual framework developed for the study is:

Independent Variables

Dependent variable

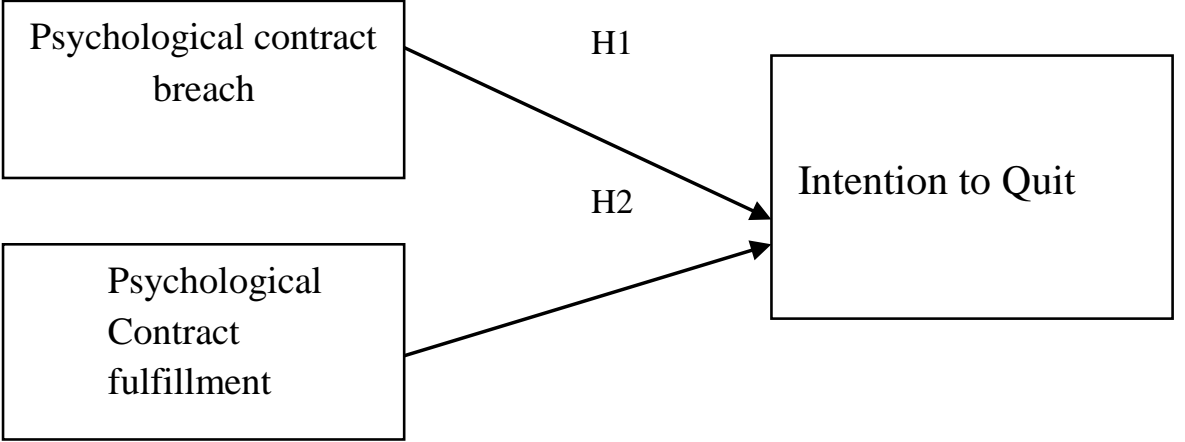

In above, research model is showing the relationship of psychological contract breach and fulfillment on employees' intention to quit in an organization. Psychological contract breach and psychological contract fulfillment are independent variables and intention to quit is the dependent variable.

Hypothesis development

The hypothesis's developed for this study are:

H 1: Psychological contract breach impact positively towards employee's to intention to quit.

H2: Psychological contract fulfillment negatively on employee retention.

\section{Data and Methodology}

This study is a primary research with the purpose to explore the effect of psychological contract breach and fulfillment on employees' intention to quit the organization. The study design is casual. To measure the responses of the respondents' questionnaire were adopted and modified according to the need of the study. Correlation and regression analysis are used to test the proposed hypothesis. The type of research is corelational/ regression and data which was used to conduct this study was primary.

This study has three variables in model, psychological contract fulfillment and breach as independent variables, where as intention to quit is studied as dependent variable. To measure Psychological contract breach and fulfillment 5 items were adapted from Robinson and Morrison (1997). In order to measure employees' intention to quit a scale was adopted from Roodt (2004), consisting of 14 items.

The population of the study comprises of Telecom Franchises from Rawalpindi /Islamabad, Pakistan as participants. The targeted respondents of this research are employees working within the organizations. A total of 250 respondents were selected on a random basis as a sample size. Convenience sampling technique was used as it made easier on the part of researcher to collect data in the short period of time and in a quicker manner.

Reliability of Instrument

Cronbach's alpha reliability statistic was used to check the data for internal consistency. The reliability values fall within the range of 0.65-0.9 which is acceptable for further statistical analysis. The results are given in table as follows: 


\section{Table 1:Reliability of Instrument}

\begin{tabular}{lcc}
\hline \hline Variables & Cronbach's Alpha & Number of items \\
\hline Psychological contract breach & .65 & 6 \\
$\begin{array}{l}\text { Psychological contract } \\
\text { fulfillment }\end{array}$ & .83 & 6 \\
$\begin{array}{l}\text { Intention to Quit } \\
\text { Data }\end{array}$ & .86 & 14
\end{tabular}

Source: Field Data

The above mentioned values confirm the reliability of the questionnaire used for the collection of data

\section{Results}

Linear regression was used to analyze the impact of psychological contract breach and psychological contract fulfillment on employees' intention to quit separately.

Psychological contract breach

Hypothesis 1, suggesting that Psychological contract breach will be positively related to employees' intention to quit, is supported: intention to quit is significantly related to psychological contract breach. Step 2 shows the results of linear regression of Psychological contract breach and intention to leave. The factor $\mathrm{R}^{2}$ shows that how much impact or effect does one variable has on the other variable. The $\mathrm{R}^{2}$ shows that $7.3 \%$ of the variation in intention to quit is explained by psychological contract breach. The $p$ value is 0.001 which is significant and it can be asserted true with $99 \%$ level of confidence. Beta value shows that there is a positive relationship between Psychological contract breach and Intention to quit $(\boldsymbol{\beta}=\mathbf{. 1 7 5}, \mathbf{p}<.00)$.

$\mathrm{R}$ change indicates 0.044 change in $\mathrm{R}$ square and it improves the relationship of PCB and IQ i.e. $=$ 0.175 and it is significant at $p=0.001$. Since the Beta coefficient has a positive value, this means there exist a direct relationship between psychological contract breach and intention to quit. Hence hypothesis 1 is proved.

Table 3: Regression analysis of Psychological contract breach

\begin{tabular}{lcccc}
\hline \hline Predictor & $\mathrm{R}^{2}$ & $\mathrm{R}^{2}$ change & Beta & Sig. F Change \\
$\beta$ & & .029 & .007 \\
Step 1 & .029 & .044 & .175 & .001 \\
\hline
\end{tabular}

Psychological contract fulfillment

Hypothesis 2, Psychological contract fulfillment will be negatively related to intention to quit is supported. In the table model one reveal that $\mathrm{R}^{2}=.148$. This means that there is $15 \%$ impact of Psychological contract fulfillment on intention to quit and the rest $85 \%$ depends on other factors which are not highlighted in this study. That is for scholars and researchers to find out/ conduct study.

The results of the analysis disclosed that the Psychological contract fulfillment posses a very strong association with intention to quit $(\boldsymbol{\beta}=\mathbf{- . 2 7}, \mathbf{p}<. \mathbf{0 0})$. $\mathrm{p}$ value is less than $1 \%$, the coefficient is highly significant and it can be asserted true with $100 \%$ level of confidence.

$\mathrm{R}$ change indicates 0.119 change in $\mathrm{R}$ square and it improves the relationship of PCF and IQ i.e. $\beta=-$ 0.265 and it is significant at $\mathrm{p}=0.000$. Beta value shows that there is a negative relationship between Psychological contract fulfillment and intention to quit.

Thus this hypothesis results suggests that employees having strong Psychological contract fulfillment within the organization will not be involved in intention to quit behavior. This proves that hypothesis 2 is accepted.

Table 4: Regression analysis of Psychological contract fulfillment

\begin{tabular}{lccc}
\hline \hline Predictor & $\mathbf{R}^{2}$ & $\mathbf{R}^{2}$ change & $\begin{array}{c}\text { Beta } \\
\boldsymbol{\beta}\end{array}$ \\
\hline Step 1 & .029 & .029 & Sig. F Change \\
Step 2 & .148 & .119 & .007 \\
\hline \hline
\end{tabular}




\section{Conclusion}

Employee retention has come forward as one of the dominant themes during the past decade. As in today's world, it has become crucial to have loyal, committed, devoted and retained workforce since, it is the competitive edge for the organization to have such employees.

The paper contributes to the existing body of literature on employees' intention to quit in the telecom organizations. There exists significant relationship of factors namely: psychological contract breach and fulfillment with intention to quit. And these factors have seen to be the most dominant attributes that will make an employee stay longer with the organization where as in case of psychological contract breach it is other wise i.e. if contract breach is observed employees can get attracted to other organizations and vice versa in case of fulfillment.

\section{References}

[1]. Aladwan, K., Bhanugopan, R., \& Fish, A. (2012). Why do employees jump ship? Examining intent to quit employment in a nonwestern cultural context. Employee Relations, 35 (4), 408-422.

[2]. Cohen, A. and Golan, R. (2007), "Predicting absenteeism and turnover intentions by past absenteeism and work attitudes", Career Development International, Vol. 12 No. 5, pp. 416-432.

[3]. Conway, N \& Briner, R.B (2005). Understanding psychological contracts at work: A critical evaluation of theory and research. Oxford, UK: Oxford University Press.

[4]. Conway, N. \& Briner, R.B. (2002). A Daily Diary Study Of Affective Responses To psychological Contract Breach And Exceeded Promises, Journal of Organizational Behavior, 23: 287-302.

[5]. Fitz-enz, J. (1997). It's costly to lose good employees. Workforce

[6]. Griffin, R.W. and Moorhead, G. (2007), Organizational Behavior: Managing People and Organizations, 8th ed., Houghton Mifflin Company, New York, NY

[7]. Griffin, R.W. and Moorhead, G. (2011), Organizational Behaviour, Cengage Learning, New York, NY

[8]. Guerrero, S., \& Herrbach, O. (2008). The Affective Underpinnings of Psychological Contract Fulfillment. Journal of Managerial Psychology, 23, $4-17$.

[9]. Hackman, J. R., \& oldham, g. R. (1980). Work redesign. Mass: addison-properties' organizational practices on employee turnover and retention. International journal of conteperooy hosp.management , 21 (4), 437-458.

[10]. Irshad, M., \& Afridi, F. (2007). Factors Affecting Employees Retention: Evidence from Literature. Abasyn Journal of Social Sciences. , 4 (2)

[11]. Lester, S.W., \& Kickul, Jill. (2001). Psychological contract in the 21st century: what employees value most and how well organizations are responding to these expectations. Human Resource Planning, 24(1), 10-21.

[12]. Lester, S.W., Turnley, W.H., Bloodgood, J.M., \& Bolino, M.C. (2002). Not seeing eye to eye: $\quad$ differences in supervisor and subordinate perceptions of and attributions for psychological contract breach. Journal of Organizational Behavior, 23: $39-56$.

[13]. Mathis, R.L. and Jackson, J. (2010), Human ResourceManagement, CengageLearning, NewYork, NY. Muhammad, M.A. and Mohammad, J.F. (2010), "Level of job satisfaction and intent to leave among Malaysian nurses", Business Intelligence Journal, Vol. 3 No. 1, pp. 123-137.

[14]. Robinson, S. (1996). Trust and breach of the psychological contract. Administrative Science Quarterly. 41, 574-599

[15]. Robinson, S., \& Morrison, E. W. (1995). Psychological contracts and OCB: The effect of unfulfilled obligations on civic virtue behavior. Journal of Organizational Behavior, 16, 289-298

[16]. Robinson, S., Kraatz M., \& Rousseau D. (1994). Changing obligations and the psychological contract: A longitudinal study. Academy of Management Journal, 37(1), 137-152.

[17]. Roodt, G. (2004), Turnover Intentions, University of Johannesburg, Johannesburg

[18]. Roodt, G. (2004a). Concept redundancy and contamination in employee commitment research: Current problems and future directions. SA Journal of Industrial Psychology, 30, 82-90.

[19]. Rousseau, D. M. (1995). Psychological contracts in organizations understanding written and unwritten agreement. Thousand Oak California. International CHRIE Conference-Refereed Track, Event 2 [2010]

[20]. Tekleab, A.G., \& M.S. Taylor (2003). Aren't there two parties in an employment relationship? Antecedents and consequences of organization-employee agreement on contract obligations and violations. Journal of Organizational Behavior, 24: 585-608. 